\title{
PENERAPAN MODEL PROJECT BASED LEARNING (PJBL) PADA POKOK BAHASAN TURUNAN FUNGSI BERDASARKAN KURIKULUM 2013 UNTUK MENINGKATKAN HASIL BELAJAR PESERTA DIDIK KELAS XI. MIA-4 SMA NEGERI 1 SUNGAILIAT
}

\author{
APPLICATION OF PROJECT BASED LEARNING MODEL (PJBL) TO IMPROVE \\ STUDENTS LEARNING OUTCOMES ON THE TOPIC OF DERIVATIVE FUNCTION \\ BASED ON CURRICULUM 2013 AT CLASS XI.MIA-4 SMA NEGERI 1 SUNGAILIAT
}

\author{
Ati Lasmanawati \\ SMA Negeri 1 Sungailiat - Bangka \\ Email: atie.0216@yahoo.co.id \\ Naskah diterima:25/02/2016, direvisi akhir: 15 /03/2016, disetujui: 03 /04/2016
}

\begin{abstract}
ABSTRAK
Penelitian ini dilakukan untuk meningkatkan hasil belajar peserta didik berdasarkan capaian kompetensi sikap, pengetahuan, dan keterampilan pada semester genap Tahun Pelajaran 2014/2015 di SMA Negeri 1 Sungailiat. Penelitian ini merupakan penelitian tindakan kelas (PTK) dengan tahapan pembelajaran, diawali dengan pengajuan pertanyaan mendasar, penyusunan desain dan jadwal kegiatan proyek, monitoring kemajuan penyelesaian proyek, menguji hasil proyek peserta didik, dan diakhiri dengan kegiatan mengevaluasi pengalaman peserta didik selama mengerjakan tugas proyek. Hasil kajian menunjukkan bahwa keberhasilan pembelajaran terlihat dari peningkatan capaian rata-rata nilai modus untuk kompetensi sikap dengan predikat baik, untuk kompetensi pengetahuan diperoleh capaian nilai rata-rata untuk setiap Kompetensi Dasar sebesar 2,80 di Siklus pertama dan di Siklus kedua sebesar 3,10 dengan presentasi kenaikan dari Siklus pertama ke Siklus kedua sebesar 30 persen. Capaian hasil belajar untuk kompetensi keterampilan, di Siklus pertama sebesar 2,96 dan Siklus kedua sebesar 3,16 dengan presentasi kenaikan dari Siklus pertama ke Siklus kedua sebesar 20 persen. Penelitian ini disimpulkan bahwa model $P j B L$ dapat meningkatkan hasil belajar peserta didik pada pokok bahasan Turunan Fungsi.
\end{abstract}

Kata Kunci: model project based learning, hasil belajar: kompetensi sikap, pengetahuan dan keterampilan peserta didik.

\begin{abstract}
This research was conducted to improve learning outcomes of students based on achievement of competence attitudes, knowledge and skills in the second semester of academic year 2014/2015 in SMA Negeri 1 Sungailiat. This was a classroom action research (PTK) on the stages of learning, beginning with the proposition of fundamental questions, preparation of design and schedule of the project activities, monitoring of project completion progress, evaluation of learners project results, and ending with activities to evaluate the experience of learners during working on project tasks. The effectivity of the learning process could be seen through the increase in the average achievement to competence mode value, which was predicate: good (B), for the knowledge competency, the average grade achieved for each Basic
\end{abstract}


Competency was 2.80 in the first cycle and 3.10 in the second cycle with 30persen increase between the first cycle to second cycle. The achievement of learning outcomes for skills competencies was 2.96 in the first cycle and 3.16 in the second cycle with 20persen increase between the first cycle to the second cycle. Itcan be concluded that PJBL model could improve students' learning outcomes on the topic of derivative function.

Keywords: Project Based Learning model, learning outcomes: competence attitudes, knowledge and students' skills.

\section{PENDAHULUAN}

Pendidikan bertujuan untuk mengembangkan potensi peserta didik agar memiliki kekuatan spiritual keagamaan, pengendalian diri, berkepribadian, memiliki kecerdasan, berakhlak mulia serta memiliki keterampilan yang diperlukan sebagai anggota masyarakat dan warga negara (UU Sisdiknas No. 20 Tahun 2003). Salah satu mata pelajaran disekolah yang dapat mendukung terciptanya hal tersebut adalah matematika, karena melalui matematika peserta didik memiliki kemampuan memperoleh, memilih dan mengelola informasi; kemampuan untuk dapat berpikir secara kritis, sistematis, logis, kreatif; dan kemampuan untuk bekerja sama secara efektif.

Soedjadi (1999) mengemukakan bahwa Matematika adalah salah satu ilmu dasar, baik pada aspek terapan maupun aspek penalarannya, mempunyai peranan yang penting dalam upaya penguasaan ilmu dan teknologi. Mata pelajaran matematika perlu diberikan kepada semua peserta didik mulai dari sekolah dasar untuk membekali peserta didik dengan kemampuan berpikir logis, analitis, sistematis, kritis, dan kreatif serta kemampuan bekerjasama (Widaningsih, 2010). Matematika diajarkan di sekolah karena matematika dapat membantu bidang studi lain seperti fisika, kimia, arsitektur, farmasi, geologi, ekonomi, statistik dan sebagainya (Karso dan Damardjo, 1993). Oleh sebab itu, matematika sebagai ilmu dasar perlu dipelajari dan dikuasai dengan baik oleh peserta didik, baik di pendidikan dasar dan menengah juga oleh mahapeserta didik di perguruan tinggi.

Seiring dengan manfaat dan kegunaanya, Sering kita dengar dari keluhan yang dilontarkan oleh sebagai besar peserta didik saat mempelajari matematika, bahwa matematika merupakan sesuatu yang tidak menyenangkan, menyulitkan, membosankan, dan memusingkan. Keluhan ini berkaitan dengan rendahnya aspek sikap positif peserta didik terhadap pelajaran dan pembelajaran matematika. Sikap positif peserta didik terhadap matematika berpengaruh terhadap prestasi belajar matematika (Sappaile, 2003; 
dalam Wahyu, 2009). Apabila penguasaan materi matematika rendah, maka akan berdampak pada aspek keterampilan matematika peserta didik, karena peserta didik yang penguasaan materi matematikanya rendah akan kesulitan untuk dapat menyelesaikan berbagai permasalahan yang mereka hadapi baik permasalahan matematika, permasalahan pada mata pelajaran lain yang berhubungan dengan materi matematika yang telah dipelajari, maupun permasalahan dalam kehidupan sehari-hari. Rendahnya penguasaan materi matematika dapat menyebabkan pembelajaran menjadi kurang bermakna.

Berdasarkan hasil diskusi dengan beberapa peserta didik kelas XI.MIA yang ada di SMA Negeri 1 Sungailiat, dengan penambahan beban belajar dalam struktur Kurikulum 2013, yaitu 4 jam di Matematika wajib dan ditambah 4 jam pada Matematika peminatan, sehingga total mereka belajar matematika dalam satu minggu adalah 8 jam, membuat mereka semakin kesulitan belajar matematika. Peserta didik merasa bahwa sulitnya materi yang harus mereka pelajari seiring dengan tingginya jenjang pendidikan yang dilampaui, membuat penguasaan materi matematika mereka semakin rendah.

Rendahnya penguasaan materi matematika yang terjadi di SMA Negeri 1 Sungailiat diantaranya pada peserta didik kelas XI.MIA4, dapat dilihat dari rendahnya capaian kompetensi sikap, pengetahuan dan keterampilan peserta didik. Apabila melihat nilai rata-rata capain kompetensi dasar (KD) pada aspek pengetahuan untuk materi sebelumnya, yaitu materi limit fungsi, hanya mencapai nilai rata-rata 2,50 (untuk rentang skala 1-4), dengan jumlah peserta didik yang melampaui nilai KKM yaitu 12 orang, dan itupun setelah dibantu oleh nilai penugasan. Karena nilaites tertulis (ulangan harian/uji kompetensi) yang dicapai peserta didik baru mencapai nilai rata-rata hanya 2,25 (untuk rentang skala nilai $1-4)$, sehingga pendidik harus melakukan kembali pembelajaran remedial klasikal. Peserta didik yang mencapai nilai KKM di tes tertulis hanya 24persen dari jumlah peserta didik yang ada di kelas, atau sekitar 8 orang peserta didik dari 32 orang. Begitu pula dengan capaian nilai rata-rata optimum dari kompetensi keterampilan peserta didik yang umumnya masih di bawah KKM, karena rendahnya nilai tes praktek peserta didik, yaitu hanya mencapai 2,30 (untuk rentang skala nilai 1-4).

Apabila ditelaah dengan lebih bijak, kenyataan yang terjadi di lapangan dari rendahnya penguasaan materi matematika yang dialami peserta didik di kelas XI.MIA-4 ini, mungkin bukan hanya karena rendahnya kemampuan peserta didik dalam pelajaran matematika peminatan, salah satunya diakibatkan oleh penyajian materi yang disampaikan oleh pendidik yang kurang tepat dan masih didominasi oleh proses pembelajaran yang hanya sekedar penyampaian materi (bersifat 
konvensional) walaupun sudah menggunakan bantuan media power point. Peserta didik selama proses pembelajaran kurang terlibat aktif, kurang bekerjasama dan saling berbagi ilmu, nampak peserta didik yang berkemampuan tinggi sangat mendominasi proses pembelajaran dan peserta didik yang berkemampuan rendah semakin lebih banyak diam dan sekedar mengikuti pelajaran.Selain itu, penyebab lain dari rendahnya penguasaan materi peminatan peserta didik di SMA Negeri 1 Sungailiat adalah belum optimalnya peserta didik memanfa'atkan materi di matematika wajib yang sudah dimiliki berkaitan dengan materi di matematika peminatan. Kondisi ini menjadi salah satu ciri bahwa kurang bermaknanya suatu proses pembelajaran.

Berdasarkan uraian di atas, pendidik harus dapat merancang pembelajaran yang sesuai dengan karakteristik Kurikulum 2013, menelaah model pembelajaran yang cocok dengan karakteristik materi yang akan disampaikan kepada peserta didik, dan menyesuaikan model yang akan digunakan dengan kemampuan peserta didik agar lebih menguasai materi yang akan dipelajari, lebih dapat mengaktifkan peserta didik dalam proses pembelajaran, lebih meningkatkan kerjasama antar pesrat didik, dan belajar untuk saling berbagi ilmu yang mereka miliki, serta dapat mengaplikasikan penguasaan materi yang diperoleh di mata pelajaran wajib untuk digunakan di mata pelajaran peminatan, khususnya dalam menyelesaikan permasalahan kehidupan sehari-hari, sehingga proses pembelajaran menjadi lebih efektif dan lebih bermakna.Salah satu model pembelajaran yang digunakan pendidik untuk menyampaikan salah satu materi matematika peminatan di kelas XI.MIA-4 untuk semester genap Tahun Pelajaran 2014/2015 pada Pokok BahasanTurunan Fungsi, yaitu penggunaan model Project Based Learning (PjBL).

Proses pembelajaran dalam model PjBL mengajak peserta didik untuk belajar lebih bermakna. Sejalan dengan pendapat Lawson (1995) bahwa proses pembelajaran yang digunakan agar menjadi lebih bermakna, maka dimulai dari pemberian pertanyaan menantang tentang suatu fenomena, kemudian menugaskan peserta didik untuk melakukan suatu aktivitas, memusatkan pada pengumpulan dan penggunaan bukti, bukan sekedar penyampaian informasi secara langsung dan penekanan pada hafalan. Proses pembelajaran yang dikemukan Lawson tersebut, ternyata terdapat pada proses pembelajaran berbasis proyek (project based learning). Penggunaan model $\mathrm{PjBL}$ ini diharapkan dapat meningkatkan sikap positif peserta didik terhadap pelajaran dan pembelajaran matematika. Dengan semakin meningkatnya sikap positif peserta didik, akan berdampak pada peningkatan hasil belajar yang lebih optimal, berupa pencapaian keseimbangan kompetensi sikap, pengetahuan dan keterampilan peserta didik dengan hasil yang lebih baik. 
Berdasarkan uraian di atas, maka rumusan masalah dari penelitian tindakan kelas ini adalah sejauh mana proses pembelajaran yang menggunakan model PjBL bermanfaat untuk meningkatkan hasil belajar matematika peminatan peserta didik kelas XI.MIA-4 pada kompetensi sikap, pengetahuan dan keterampilan Tahun Pelajaran 2014/2015 pada pokok bahasan Turunan Fungsi berdasarkan Kurikulum 2013 di SMA Negeri1 Sungailiat. Tujuan dari penelitian ini adalah untuk menelaah peran proses pembelajaran yang menggunakan model PjBL dalam meningkatkan hasil belajar matematika peminatan peserta didik kelas XI.MIA-4 pada kompetensi sikap, pengetahun, dan keterampilan Tahun Pelajaran 2014/2015 pada pokok bahasan Turunan Fungsi berdasarkan Kurikulum 2013 di SMA Negeri 1 Sungailiat.

\section{KAJIAN LITERATUR}

\section{Model Project Based Learning (PjBL)}

Model ini adalah model pembelajaran yang mengorganisasikan kelas menggunakan proyek atau kegiatan sebagai inti pembelajaran (Thomas, 2000). The George Lucas Educational Foundation (2005) mendefinisikan Model PjBL sebagai pendekatan pembelajaran yang dinamis di mana peserta didik secara aktif mengeksplorasi masalah di dunia nyata, memberikan tantangan, dan memperoleh pengetahuan yang lebih mendalam. Menurut penelitian Barron \& Darling-Hammond (2008) dan Thomas (2000), bahwa model $P j B L$ pada dasarnya melibatkan peserta didikuntuk belajar pengetahuan berkaitan bagaimana cara mengatasi masalah nyata, meningkatkan kontrol peserta didik terhadapkegiatan belajar, menjadikan guru sebagai pelatih dan fasilitator dalam penyelidikan maupun saat refleksi, dan membuat peserta didik bekerja kelompok.

Global School Net (2000; dalam Kemendikbud, 2014) melaporkan hasil penelitian The Auto Desk Foundation tentang karakteristik model PjBL. Model ini mempunyai delapan karakteristik. Karakteristik pertama, peserta didik membuat keputusan tentang sebuah kerangka kerja. Kedua, adanya permasalahan atau tantangan yang diajukan kepada peserta didik. Ketiga, peserta didik mendesain proses untuk menentukan solusi atas permasalahan atau tantangan yang diajukan. Keempat, peserta didik secara kolaboratif bertanggungjawab untuk mengakses dan mengelola informasi untuk memecahkan permasalahan. Kelima, proses evaluasi dijalankan secara kontinu. Keenam, peserta didik secara berkala melakukan refleksi atas aktivitas yang sudah dijalankan. Ketujuh, produk akhir aktivitas belajar akan dievaluasi secara kualitatif. Kedelapan, situasi pembelajaran sangat toleran terhadap kesalahan dan perubahan. Karakteristik yang ada pada model $P j B L$ inilah yang dapat membuat peserta didik belajar mengembangkan kreativitas berpikir, pemecahan masalah, dan interaksi antara 
peserta didik dengan kawan sebaya mereka untuk menciptakan dan menggunakan pengetahuan baru.

Model PjBL merupakan model pembelajaran yang memberikan kebebasan kepada peserta didik untuk merencanakan aktivitas belajar dan melaksanakan proyek secara kolaboratif. Salah satu dari empat komponen esensial pengetahuanyang didesain dalam model PjBL adalah adanya kolaborasi (kerjasama) yang dibangun sesama peserta didik (Blumenfeld, 2000 dalam Rais, 2010). Dengan bekerjasama, para peserta didik terbantu dalam menemukaan persoalan, merancang rencana, dan mencari pemecahan masalah (Jhonson, 2010). Peserta didik secara kritis mengungkapkan ide-ide dalam kelompok kolaboratif, mulai dari merencanakan sesuatu tentang cara memperoleh pengetahuan, memproses secara kolaboratif dan bermakna, menyimpulkan, hingga saling menukar informasi di antara kelompok sebelum kemudian mempresentasikan hasil kerja kelompok kepada kelompok lain.

Penerapan Model PjBL dalam penelitian ini dilaksanakan dengan mengacu pada The George Lucas Educational Foundation dalam Kemendikbud (2014). Penerapan model ini dilaksanakan dalam enam langkah, yaitu (i) penentuan pertanyaan mendasar, mendesain perencanaan proyek, (iii) menyusun jadwal, (iv) memonitor peserta didik dan kemajuan proyek, (v) menguji hasil, dan (vi) mengevaluasi pengalaman.

Pada proses pembelajaran menggunakan model $P j B L$, konsep-konsep awal yang telah dipelajari peserta didik pada materi matematika wajib akan di gunakan untuk mendapatkan konsep-konsep baru pada matematika peminatan, sehingga peserta didik mendapatkan makna dari apa yang telah dipelajari. Peserta didik diberi kesempatan untuk menggali sendiri informasi melalui membaca berbagaibuku secara langsung, membuat presentasi untuk orang lain, mengkomunikasikan hasil aktivitasnya kepada orang lain, bekerja dalam kelompok, memberikan usul atau gagasannya untuk orang lain dan berbagai aktivitas lainnya. Ketika peserta didik mempelajari sesuatu dan dapat menemukan makna, maka makna tersebut akan memberi mereka alasan untuk belajar (Johnson, 2007).

Teori-teori belajar yang mendukung pengembangan model $P J B L$, diantaranya adalah teori belajar bermakna yaitu agar belajar bermakna, konsep baru atau informasi baru harus dikaitkan dengan konsep-konsep yang sudah ada dalam struktur kognitif peserta didik (Ausebel dalam Trianto, 2007). Belajar bermakna akan terjadi apabila peserta didik mencoba menghubungkan fenomena baru ke dalam struktur pengetahuan mereka saat menyelesaikan masalah (Suparno, dalam Heruman, 2010). Dalam membantu peserta 
didik menanamkan pengetahuan baru dari suatu materi, sangat diperlukan konsep-konsep awal yang sudah dimiliki oleh peserta didik yang berkaitan dengan konsep yang akan dipelajari. Seorang peserta didik harus dapat mengubungkan apa yang dimiliknya dalam struktur berpikirnya yang berupa konsep matematika, dengan permasalahan yang dihadapinya (Heruman, 2010).

Teori belajar lain yang mendukung pengembangan model $P j B L$ adalah teori belajar konstruktivisme (Trianto, 2007), yang mengemukakan bahwa peserta didik harus menemukan sendiri dan mentrasnformasikan informasi kompleks, mengecek informasi baru dengan aturan-aturan lama dan merevisinya apabila aturan-aturan itu tidak lagi sesuai. Prinsip yang paling penting adalah pendidik tidak hanya sekedar memberikan pengetahuan kepada peserta didik, karena peserta didik harus membangun sendiri pengetahuan di dalam benaknya. Menurut teori penemuan dari Jerome Bruner (Ruseffendi, 1991), peserta didik dalam belajar matematika harus menemukan sendiri berbagai pengetahuan yang diperlukannya. Oleh karena itu, kepada peserta didik materi disajikan bukan dalam bentuk akhir dan tidak diberitahukan cara penyelesaiannya, dalam proses pembelajaran ini, pendidik harus lebih berperan sebagai pembimbing dibandingkan sebagai pemberi tahu.
Teori terakhir yang mendukung model PjBL adalah teori pembelajaran sosial Vigotsky (Trianto, 2007) yang mengemukakan bahwa pembelajaran akan terjadi jika anak bekerja atau menangani tugas-tugas yang belum dipelajari, namun tugas-tugas itu masih dalam jangkauan mereka (zone of proximal development), dan pendidik memberikan scaffolding yaitu pemberian bantuan kepada peserta didik selama tahap-tahap awal perkembangannya dan mengurangi bantuan tersebut dengan memberikan kesempatan kepada peserta didik untuk mengambil alih tanggung jawab yang semakin besar segera setelah anak dapat melakukannya. Dengan kata lain, bahwa peserta didik sebaiknya diberikan tugas-tugas kompleks, sulit, dan realistik, kemudian diberi bantuan secukupnya untuk menyelesaikan tugas-tugas itu.

\section{Hasil Belajar}

Belajar adalah suatu proses perubahan di dalam kepribadian manusia dan perubahan tersebut ditampakan dalam bentuk peningkatan kualitas dan kuantitas tingkah laku seperti peningkatan kecakapan, pengetahuan, sikap, kebiasaan, pemahaman, keterampilan, daya pikir, dan kemampuan lainnya. dalam belajar, hal yang terpenting adalah proses bukan hasil yang diperoleh (Hakim, 2005). Artinya belajar harus diperoleh dengan usaha sendiri, adapun orang lain hanyalah perantara atau penunjang dalam kegiatan belajar agar belajar itu berhasil dengan baik. 
Seluruh kecakapan dan segala hal yang diperoleh melalui proses belajar mengajar di sekolah yang dinyatakan dengan angka dan diukur dengan menggunakan tes hasil belajar (Briggs, 1979). Tingkat kemajuan dan ketercapaian hasil belajar dari tujuan pembelajaran dapat dilihat melalui proses evaluasi pembelajaran atau tes hasil belajar. Dengan penilaian hasil belajar maka dapat diketahui seberapa besar keberhasilan peserta didik telah menguasai kompetensi atau materi yang diajarkan oleh pendidik, dan penilaian pun dapat digunakan sebagai acuan untuk melihat tingkat keberhasilan atau efektivitas pendidik dalam pembelajaran (Kunandar, 2013).

Keberhasilan belajar peserta didik dalam mencapai kompetensi yang telah ditetapkan berdasarkan penilaian hasil belajar oleh pendidik, terhadap penguasaan tingkat kompetensi sebagai capaian pembelajaran yang merupakan batas minimal pencapaian kompetensi sikap, kompetensi pengetahuan, dan kompetensi keterampilan (Kunandar, 2013). Berdasarkan hasil penilaian pendidik, kompetensi sikap menggunakan teknik observasi, hasil penilaian kompetensi pengetahuan menggunakan teknik tes tertulis (ulangan harian) dan penugasan, serta hasil penilaian kompetensi keterampilan berdasarkan tes praktik/unjuk kerja dan proyek.

\section{Penelitian Relevan}

Penelitian yang membandingkan hasil belajar bagi peserta didik yang diajarkan melalui model PjBL dengan pembelajaran tradisional, ternyata model PjBL dapat meningkatkan retensi jangka panjang dari konten, membantu peserta didik menyelesaikan tes tingkat tinggi, meningkatkan pemecahan masalah dan keterampilan kolaborasi, serta meningkatkan sikap peserta didik terhadap pembelajaran (Strobel \& van Barneveld, 2009; Walker \& Leary, 2009; dalam The George Lucas Educational Foundation, 2012). Sejalan dengan penelitian yang dilakukan oleh Lindawati, Fatmariyanti\& Miftukhin (2013), diperoleh kesimpulan bahwa pelaksanaan pembelajaran Fisika melalui pembelajaran project based learning dapat meningkatkan kreativitas peserta didik kelas X.6 MAN 1 Kebumen. Hal ini dapat dilihat dari meningkatnya rerata persentase hasil observasi, angket, tes essay dan hasil belajar peserta didik. Hasil penelitian Utami, Probosari, Fatmawati (2015) mengemukakan bahwa ada pengaruh model pembelajaran $P j B L$ berbantu Instagram terhadap kemampuan berpikir kreatif peserta didik kelas X SMA Negeri 8 Surakarta dengan didukung dari hasil rata-rata peserta didik pada kelas eksperimen $(82,72)$ lebih tinggi dibanding dengan kelas kontrol $(77,12)$.

\section{METODOLOGI PENELITIAN}

Berdasarkan proses pengumpulan dan pengolahan data yang digunakan dalam penelitian ini, penelitian ini dapat dikategorikan sebagai salah satu jenis 
penelitian tindakan kelas/ Classroom Action

Research (CAR). Suparno (2008) mengemukakan bahwa penelitian tindakan merupakan upaya yang dilakukan oleh guru kelas untuk memperbaiki cara mengajar mereka sehari-hari, dengan tujuan memperbaiki keadaan proses belajar mengajar di kelas atau kinerja guru tersebut.

Desian penelitian tindakan kelas dalam penelitian ini sesuai dengan pendapat Kemmis dan McTagger (1990) yaitu penelitian yang berSiklus yang terdiri dari Rencana (plan), Aksi (act) dan Observasi (observe), serta Refleksi (reflect) yang dilakukan secara berulang (Gambar 1).

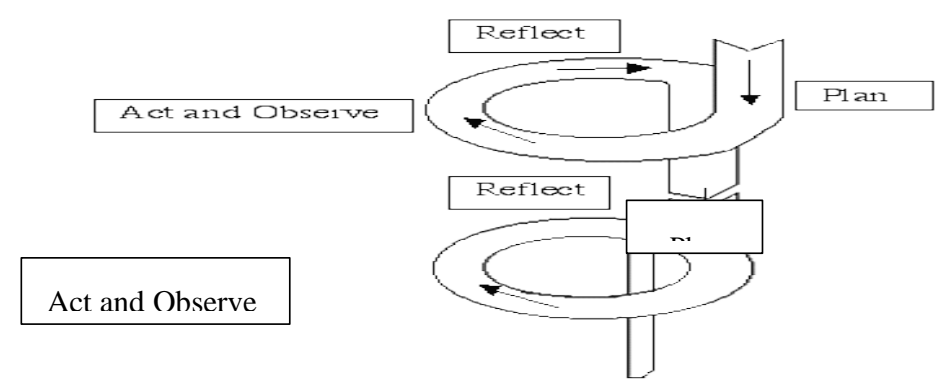

Gambar 1 Siklus Penelitian Tindakan Kelas (PTK) Sumber: Kemmis dan McTagger (1990)

Penelitian ini dilaksanakan pada semester Genap Tahun Pelajaran 2014/2015 selama \pm 5 minggu atau 5 pertemuan dengan alokasi waktu setiap pertemuan $4 \times 45$ menit (180 menit), yang dimulai dari akhir bulan April 2015 s.d. akhir bulan Mei 2015. Penelitian yang dilakukan terhadap peserta didik SMA Negeri 1 Sungailiat Kelas XI.MIA-4 dengan jumlah peserta didik 32 orang ini, membahas pokok bahasan Turunan Fungsi, yaitu Bab 6 tentang Turunan Fungsi Trigonometri dan Bab 7 tentang Aplikasi Turunan Fungsi.

Instrumen penelitian yang digunakan selama proses pembelajaran untuk melihat peningkatan hasil belajar peserta didik berdasarkan aspek sikap, pengetahuan maupun keterampilan sesuai dengan karakteristik penilaian dalam Kurikulum 2013, yaitu untuk aspek sikap menggunakan lembar observasi, dan aspek pengetahuan menggunakan lembartes tertulis dengan penugasan. Pada aspek keterampilan, instrumen penilaian yang digunakan adalah lembar tes praktek/unjuk kerja dan proyek. Validasi Instrumen penelitian dengan uji validasi yang menggunakan rumus koefisien product moment, dan validitas konstruk instrumen dilakukan oleh ahli.

Data yang dikumpulkan selama proses penelitian dianalisis sesuai dengan Permendikbud Nomor 104 Tahun 2014 tentang Penilaian Hasil Belajar oleh Pendidik Pada Pendidikan Dasar dan Menengah, bahwa data hasil observasi dinalisis dengan melihat 
nilai sikap yang dominan muncul (modus) dari peserta didik berdasarkan data-data yang diamati/diobservasi selama proses pembelajaran berlangsung. Untuk mengolah data hasil tes tertulis dan penugasan, dengan melihat nilai setiap KD, kemudian diambil nilai rata-rata dari jumlah nilai keseluruhan KD yang diujikan. Untuk penilaian pada aspek keterampilan, baik pada penilaian tes praktek/unjuk kerja dan proyek dengan melihat nilai optimum yang diperoleh peserta didik untuk setiap KD, dan mengambil nilai rata-rata dari nilai optimum setiap $\mathrm{KD}$.

\section{HASIL DAN PEMBAHASAN}

Pelaksanaan pembelajaran dengan menggunakan model $P j B L$, dalam penelitian ini diawali dengan penentuan pertanyaan mendasar (start with the essential question), yaitu pertanyaan yang dapat memberi penugasan peserta didik dalam melakukan suatu aktivitas. Pada kegiatan pertama, peserta didik bersama kelompoknya mengamati gambar/fakta-fakta yang berkaitan dengan materi Turunan Fungsi yang sudah dikenal peserta didik dalam kehidupan sehari-hari yang disajikan disajikan dalam lembar kerja. Berdasarkan hasil pengamatan, peserta didik membuat pertanyaan mendasarkan dan mencari permasalahan lain, baik dalam kehidupan sehari-hari, kaitan dengan mata pelajaran lain, maupun dengan materi matematika di pokok bahasan yang berbeda dengan mencari dari berbagai sumber sebagai bahan tugas proyek. Kegiatan ini mengajak peserta didik untuk berpikir kritis dan kreatif. Hal ini sesuai dengan pendapat Bjorner, Kofoed, \& Pederson (2012) bahwa pembelajaran berbasis proyek harus mengaktifkan peserta didik untuk kreatif selama penyelesaian proyek.

Kegiatan yang kedua, mendesain perencanaan proyek (design a plan for the project), yang merupakan kegiatan kolaboratif antar peserta didik maupun dengan guru dalam menyusun aturan-aturan dalam penyelesaian proyek. Kegiatan ini mengajak peserta didik untuk saling berkolaborasi dan bekerjasama, agar desain rancangan penyelesaian tugas proyek dapat diselesaikan dengan baik. Jhonson (2010) mengemukakan bahwa dengan bekerjasama, para peserta didik terbantu dalam menemukaan persoalan, merancang rencana, dan mencari pemecahan masalah.

Kegiatan ketiga, menyusun jadwal (create a schedule), dengan aktivitas: membuat timeline penyelesaian proyek, membuat deadline penyelesaian proyek, membimbing peserta didik agar merencanakan cara yang baru, membimbing peserta didik ketika mereka membuat cara yang tidak berhubungan dengan proyek, dan meminta peserta didik untuk membuat penjelasan (alasan) tentang pemilihan suatu cara.

Kegiatan ke-empat, yaitu memonitor peserta didik dan kemajuan proyek (monitor the students and the progress of the project), 
dengan menggunakan rubrik yang dapat merekam keseluruhan aktivitas yang penting. Selama kegiatan ini, peserta didik mengolah informasi dan melakukan investigasi terhadap masalah, memilih strategi untuk dapat menyelesaikan masalah proyek, melaksanakan diskusi kelompok, memfasilitasi penyusunan hasil kerja proyek dan memfasilitasi pembuatan laporan. Hal tersebut sesuai dengan pendapat Sugiyastini (2013; dalam Utami, 2013) yang menyatakan bahwa model PjBL dirancang untuk menyelesaikan permasalahan yang kompleks yang diperlukan peserta didik dalam melakukan investigasi dan memahaminya.

Kegiatan ke-lima, menguji hasil (assess the outcome), sebagai bentuk penilaian untuk mengukur ketercapaian kompetensi, mengevaluasi kemajuan masing-masing peserta didik, dan memberi umpan balik terhadap pemahaman yang sudah dicapai peserta didik. Peserta didik bersama anggota kelompoknya membuktikan jawaban-jawaban dari pertanyaan mendasar maupun pertanyaan yang ditemukan dari internet maupun buku lain yang relevan sebelum menuliskan pada makalah (menghubungkan jawaban yang diperoleh dari hasil diskusi dengan teori-teori yang ditemukan baik dari berbagai sumber. Kegiatan terakhir yaitu mengevaluasi pengalaman (evaluate the experience), dimana pendidik dan peserta didik melakukan refleksi terhadap aktivitas dan hasil proyek yang sudah dijalankan dengan cara mengungkapkan pengalamanya selama menyelesaikan proyek. Pendidik dan peserta didik mengembangkan diskusi untuk memperbaiki kinerja selama proses pembelajaran, sehingga pada akhirnya ditemukan suatu temuan baru (new inquiry) untuk menjawab permasalahan, dan menjadikan pembelajaran lebih bermakna. Sejalan dengan Wena (2009) bahwa model $P j B L$ merupakan sebuah model pembelajaran yang inovatif, dan lebih menekankan pada belajar kontekstual melalui serangkaian kegiatan yang kompleks. Pembelajaran berbasis proyek memiliki potensi yang besar untuk memberi pengalaman belajar yang lebih menarik dan bermakna bagi peserta didik.

\section{Siklus Pertama}

Berdasarkan hasil pengamatan peneliti selama kegiatan belajar menggunakan model PjBLuntuk Siklus pertama yang selanjutnya di analisis oleh peneliti, ditemukan hal-hal sebagai berikut:

a) Adanya peningkatan hasil belajar peserta didik baik dari aspek kompetensi sikap, pengetahuan maupun keterampilan walaupun belum optimal (data terlampir pada gambar 4.1).

b) Hasil belajar untuk aspek kompetensi keterampilan peserta didik setelah menggunakan model $P j B L$, untuk tes praktek masih didominasi oleh ketua kelompok.

c) Kegiatan mengamati tayangan tentang topik yang akan dibahas, dan membuat pertanyaan mendasar sebagai bahan tugas 
proyek tanpa berkelompok, ternyata kurang efektif.

d) Penyusunan desain/rencana kegiatan dan jadwal kegiatan yang tidak menuliskan petugas atau peserta didik yang mengerjakan tugas di setiap kelompoknya, membuat penyelesaian tugas kelompok lebih didominasi oleh ketua kelompok, dan terkesan anggota kelompok hanya mengikuti saja apa yang dikerjakan oleh ketuanya.

e) Masih banyaknya kelompok yang tidak membawa laptop di Siklus pertama ini, sehingga penyusunan desian dan jadwal kegiatan dilakukan bersama pendidik masih menggunakan buku catatan atau kertas coretan. f) Berdasarkan pengamatan peneliti selama proses presentasi, karena bahan yang sama dari setiap kelompok dipresentasikan, membuat peserta didik yang tidak tampil kurang serius memperhatikan.

g) Saat dilakukan evaluasi atau uji kompetensi (tes tertulis), nampak masih ada peserta didik yang mencuri-curi kesempatan untuk bertanya dengan rekannya.

h) Berikut ini diagram hasil belajar peserta didik kelas XI.MIA-4 berdasarkan aspek kompetensi sikap, pengetahuan dan keterampilan, yang proses pembelajarannya sebelum (pra Siklus) dan sesudah (Siklus 1) menggunakan Model PjBL (Gambar 2).

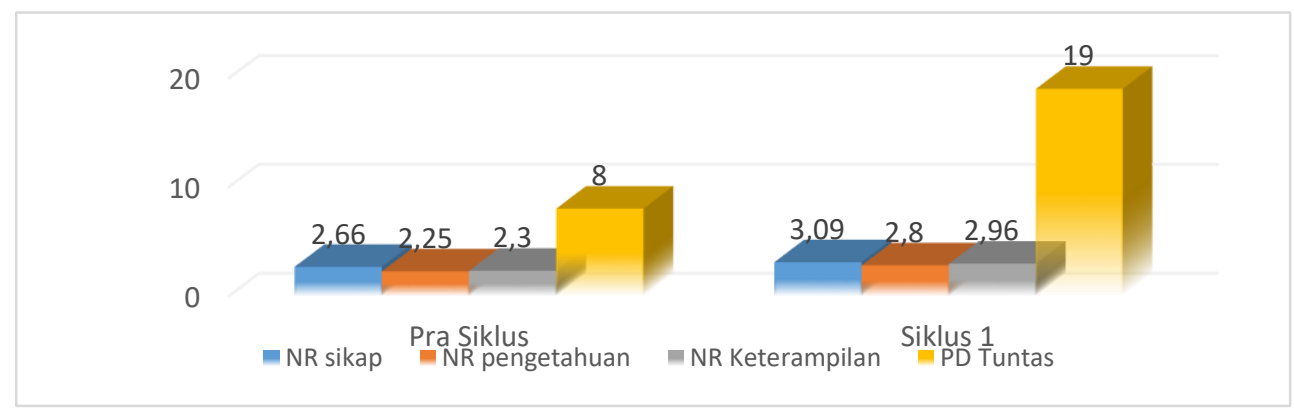

Gambar 2 Hasil Belajar Peserta Didik setelah Siklus 1

Berdasarkan hasil pengamatan selama implementasi berlangsung pada Siklus pertama terdapat beberapa hal yang dapat diajukan sebagai perbaikan dalam Siklus kedua sebagai hasil dari refleksi.

a) Hasil belajar peserta didik untuk kompetensi sikap, dirasa perlu untuk ditingkatkan lagi agar lebih optimal;

b) Pada aspek kompetensi sikap, rasa kerjasama, kekompakan dan rasa saling membantu/peduli diantara anggota kelompok, disiplin, tanggung jawab, kerja keras untuk dapat menyelesaikan tugas bersama,dan berusaha untuk selalu kritis menghadapi permasalahan yang diberikan pendidik, dirasa perlu untuk ditingkatkan lagi.

c) Agar hasil belajar dapat lebih baik lagi, maka semua anggota kelompok harus bersama-sama mengerjakan tugas proyek 
yang diberikan, dan akan tertulis di desian/rencana kegiatan dan jadwal kegiatan nama-nama petugas yang berperan menyelesaikan tugas proyeknya.

d) Agar pengerjaan desian/rencana dan jadwal kegiatan sudah dapat dilakukan di dalam kelas, maka pendidik sudah menginformasikan kepada peserta didik untuk membawa laptop setiap ada pertemuan dengan pendidik (jam pelajaran matematika peminatan) sehingga proses bimbingan dan pencarian informasi mulai dapat dilakukan di dalam kelas, tidak mengandalkan kegiatan setelah pulang sekolah.

e) Agar tidak ada lagi celah bagi peserta didik yang berusaha untuk tidak berperilaku jujur (nyontek), apalagicopy paste maka setiap kelompok diminta untuk mencari permasalahan yang berbeda.

f) Pengumpulan tugas proyek sebaiknya tidak dilakukan saat akan presentasi, tetapi pengumpulan tugas dilakukan beberapa hari sebelum kegiatan presentasi dilakukan.

g) Agar peserta didik lebih siap saat dilakukan evaluasi atau uji kompetensi (tes tertulis), maka pendidik harus selalu mengingatkan peserta didik kapan akan diadakan evaluasi akhir, sehingga peserta didik dapat mempersiapkan diri.

h) Agar penyampaian pengalaman peserta didik selama menyelesaikan tugas proyek, dilakukan oleh semua kelompok.

\section{Siklus Kedua}

Berdasarkan hasil pengamatan peneliti selama kegiatan belajar menggunakan model PjBLuntuk Siklus kedua yang selanjutnya di analisis oleh peneliti, ditemukan hal-hal sebagai berikut:

a) Adanya peningkatan hasil belajar peserta didik baik dari aspek kompetensi sikap, pengetahuan maupun keterampilan yang lebih optimal. Hasil kegiatan belajar di Siklus kedua ini, dapat dilihat dari diagram Siklus 4.2, dengan jabaran dari setiap aspek kompetensi, yaitu:

b) Hasil belajar peserta didik berdasarkan aspek kompetensi sikap terhadap pelajaran dan pembelajaran matematika setelah menggunakan model PjBL, ternyata mengalami peningkatanbaik dari segi keaktifan, disiplin, kerjasama, toleransi, dan kebiasaan berpikir kritis, sikap peduli, rela bekerja keras, dan rasa tanggung jawab dari setiap anggota kelompok.

c) Hasil belajar peserta didik untuk aspek kompetensi pengetahuan setelah menggunakan model PjBL di Siklus kedua ini, ternyata nilai rata-ratanya semakin meningkat menjadi 3,10dengan capain peserta didik yang tuntas menjadi 29 orang dari 32 orang yang ada dalam rombongan belajar.

d) Hasil belajar untuk aspek kompetensi keterampilan peserta didik setelah menggunakan model $P j B L$, saat prsentasi tidak lagi didominasi oleh ketua kelompok karena yang tampil presentasi sudah melalui proses undian. 
e) Peserta didik secara berkelompok sudah aktif mengamati, saling bertanya dan membuat pertanyaan mendasar, membuat desain/rencana dan jadwal kegiatan tugas proyek, maupun mencari informasi melalui internet saat di lingkungan sekolah.

f) Setiap kelompok sudah membawa laptop dan sehingga di Siklus kedua ini kegiatan di dalam kelas sudah mencari informasi bukan hanya dari buku paket atau buku-buku yang relevan, namun mereka sudah browsinginternet untuk mencari bahan penyelesaian diskusi kelompoknya.

g) Karena bahan yang dipresentasikan tidak lagi sama untuk setiap kelompok, membuat peserta didik yang tidak tampil lebih serius memperhatikan. h) Selalu mengingatkan peserta didik bahwa akan ada evaluasi akhir (tes tertulis) setelah sesi presentasi, membuat semua peserta didik saat dilakukan evaluasi atau uji kompetensi (tes tertulis) sudah lebih siap dan tidak ada lagi yang peserta didik yang mencuri-curi kesempatan untuk bertanya dengan rekannya, mereka sudah memilki rasa percaya diri dan berusaha untuk menyelesaikan soal evaluasi dengan mengadalkan kemampuanya sendiri.

i) Berikut ini diagram hasil belajar peserta didik kelas XI.MIA-4 berdasarkan aspek kompetensi sikap, pengetahuan dan keterampilan, yang proses pembelajarannya sebelum (pra-Siklus) dan sesudah (Siklus 1 dan Siklus 2) menggunakan Model PjBL:

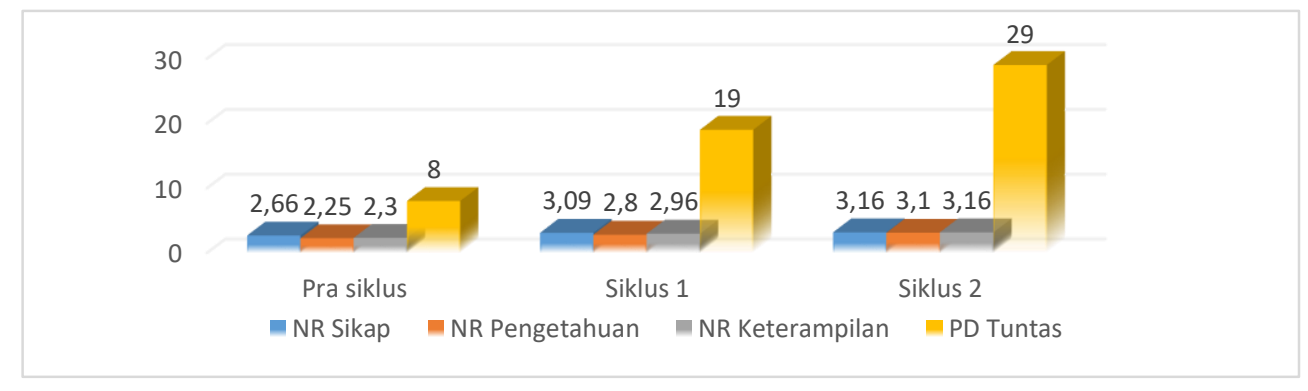

Gambar 3 Diagram 1 Hasil Belajar Peserta Didik setelah Siklus 2

Berdasarkan hasil pengamatan selama implementasi berlangsung pada Siklus kedua, terdapat beberapa hal yang dapat dijadikan sebagai bahan refleksi dari hasil evaluasi yang dilakukan peneliti.

a) Hasil belajar peserta didik untuk kompetensi sikap, pengetahuan dan keterampilan terhadap pelajaran maupun pembelajaran sudah dianggap sudah baik; b) Pada aspek kompetensi sikap, adanya rasa kerjasama, kekompakan dan rasa saling membantu/peduli diantara anggota kelompok, disiplin, tanggung jawab, kerja keras untuk dapat menyelesaikan tugas bersama,dan berusaha untuk selalu kritis menghadapi permasalahan yang diberikan pendidik sudah mengalami peningkatan dengan baik. Peserta didikbersama 
kelompoknya sudah dapat belajar untuk saling membantu/ menjadi tutor bagi yang belum paham, sehingga setiap anggota kelompok dapat lebih menguasai materi yang dipelajari, dan saat mengerjakan permasalahan pun dapat dilakukan bersamasama.

c) Kegiatan mengamati bahan/fakta-fakta yang berkaitan dengan materi Aplikasi Turunan Fungsi, baik yang disajikan pendidik melalui lembar kerja maupun yang ada di buku paket, dan membuat pertanyaan mendasar yang akan dijadikan bahan tugas proyek yang dilakukan secara berkelompok, membuat peserta didik lebih aktif dan lebih kritis saat mengamati, saling bertanya dan membuat pertanyaan mendasar, membuat desain/rencana dan jadwal kegiatan tugas proyek, maupun mencari informasi melalui internet.

d) Semua kelompok sudah membawa laptop, sehingga pengerjaan desian/rencana dan jadwal kegiatan sudah dapat dilakukan di dalam kelas, dan peserta didik yang sudah terkoneksi dengan internet, sudah mulai melakukan pengumpulan data untuk penyelesaian tugas proyeknya.

e) Semua anggota kelompok bersama-sama mengerjakan tugas proyek yang diberikan, dan nama setiap petugas tertulis di desain/rencana kegiatan maupun jadwal kegiatan setelah dibuat format tabel yang mencantumkan nama setiap anggota di aktifitas kegiatan penyelesaian tugas proyek membuat setiap anggota kelompok sudah menunjukkan rasa tanggung jawab dan peduli untuk menyelesaikan tugas.

f) Setiap kelompok sudah dapat menemukan permasalahan yang berbeda dan menyelesaikan tugas proyek yang diberikan dengan gaya masing-masing setiap kelompok. Setiap kelompok akan menyajikan topik yang berbeda bukan bahan yang sama, sehingga wawasan peserta didik lebih luas dan permasalahan yang disajikan dapat lebih beragam bukan hanya membahas lingkup permasalahan yang sama.

g) Pengumpulan tugas proyek yang dilakukan beberapa hari sebelum presentasi, dan mengundi kelompok maupun peserta didik yang akan tampil presentasi ternyata membuat peserta didik lebih siap saat tampil presentasi di depan kelas, dan peserta didik lebih menguasai materi sehingga berdampak pada capaian hasil tes praktek yang diraih peserta didik. Selain itu, adanya konsultasi dengan pendidik sebelum tampil presentasi, memberi kesempatan kepada peserta didik untuk dapat memperbaiki makalahnya. Sistem pengundian saat akan presentasi pun ternyata membuat peserta didik yang berkemampuan lebih baik (sudah memahami materi) mau menurunkan ilmunya kepada rekan sekelompoknya, sehingga yang meraih ketuntasan dalam capaian hasil belajar bukan hanya didominasi yang pandai saja, tapi semua peserta didik secara klasikal sudah dapat meraih nilai tuntas. 
h) Penyampaian pengalaman peserta didik selama menyelesaikan tugas proyek yangdilakukan oleh perwakilan dari setiap kelompok, ternyata memberikan masukan kepada pendidik untuk mengevaluasi yang menjadi kendala, hambatan, kesulitan maupun pengalaman yang positif yang semua peserta didik rasakan saat menyelesaikan tugasnya.

i) Setelah kegiatan Siklus kedua, ternyata penggunaan model $P j B L$ sudah dapat meningkatkan hasil belajar peserta didik berdasarkan capaian sikap, pengetahuan dan keterampilan yang cukup optimal. Hal ini ditunjukkan dengan capain ketuntasan peserta didik dalam uji kompetensi pengetahuan (tes tertulis) secara klasikal, maupun ketuntasan peserta didik pada kompetensi sikap dan keterampilan. Oleh karena itu, peneliti hanya melakukan kegiatan pembelajaran dengan model $P j B L$ sampai dengan Siklus kedua.

Berikut adalah tabel hasil belajar peserta didik berdasarkan aspek kompetensi sikap, pengetahuan dan keterampilan untuk Pokok Bahasan Turunan Fungsi, baik pada Bab Turunan Fungsi Trigonometri maupun Bab Aplikasi Turunan Fungsidi kelas XI.MIA-4 pada semester genap Tahun Pelajaran 2014/2015:

Tabel 1. Hasil Belajar Peserta DidikBerdasarkan Capaian Kompetensi Sikap, Pengetahuan dan Keterampilan

\begin{tabular}{|c|c|c|c|c|c|}
\hline No. & Pelaksanaan Pembelajaran & $\begin{array}{c}\text { Rata-rata Nilai Sikap } \\
\text { (Observasi) } \\
\text { KD } 1.1,2.1,2.2,2.3\end{array}$ & $\begin{array}{c}\text { Rata-rata Nilai } \\
\text { KD Pengetahuan }\end{array}$ & $\begin{array}{c}\text { Rata-rata Nilai } \\
\text { Optimum } \\
\text { Keterampilan }\end{array}$ & $\begin{array}{c}\text { Jumlah Peserta } \\
\text { Didik Tuntas }\end{array}$ \\
\hline 1. & Pra Siklus & C (2,66) & C (2,25) & C (2,30) & $\mathbf{8}$ \\
\hline 2. & $\begin{array}{c}\text { Siklus 1 } \\
(\text { KD 3.11, 3.12, 4.9, 4.10) }\end{array}$ & B (3,09) & B- (2,80) & B (2,96) & $\mathbf{1 9}$ \\
\hline 3. & $\begin{array}{c}\text { Siklus 2 } \\
(\text { KD 3.13, 4.11) }\end{array}$ & B (3,16) & B (3,10) & B (3,16) & $\mathbf{2 9}$ \\
\hline
\end{tabular}

Capaian kompetensi sikap peserta didik setelah proses pembelajarannya menggunakan model $P j B L$ dari pra Siklus sampai Siklus kedua memang di nilai modus B (baik). Namun apabila hasil penilaian observasi yang dilakukan peneliti dianalisis dengan baik, ternyata capaian yang diperoleh peserta didik untuk setiap indikator yang menjadi bahan penilaian pada kompetensi sikap mengalami peningkatan. Capai nilai sikap di Siklus pertama rata-rata hanya mendapat nilai $\mathrm{B}$, bahkan ada pula peserta didik yang mendapat nilai C (cukup), namun di Siklus kedua ini ratarata peserta didik sudah meraih nilai $\mathrm{B}$ (baik) dan SB (amat baik) untuk beberapa indikator dari kompetensi sikap yang diukur. 
Peningkatan capaian nilai sikap dengan indikator bekerjasama dalam kegiatan diskusi kelompok, disiplin dalam kegiatan pembelajaran, bertanggung jawab dalam kegiatan melaksanakan tugas yang diberikan, rasa ingin tahu dalam menyelesaikan permasalahan, dan toleransi terhadap perbedaan pendapat, ternyata berpengaruh terhadap nilai aspek pengetahuan. Capaian nilai per Kompetensi Dasar (KD) untuk aspek pengetahuan.yang diperoleh peserta didik dapat dilihat dari hasil analisis, bahwa peserta didik yang belum mencapai nilai tuntas untuk rata-rata nilai per $\mathrm{KD}$ hanya bersisa 3 orangdari 32 orang peserta didik yang ada dalam rombongan belajar. Ini menunjukkan bahwa capaian kompetensi pengetahuan peserta didik di kelas XI.MIA-4 pada umumnya sudah melampaui batas KKM, dengan besarnya nilai rata-rata untuk kompetensi pengetahuan berdasarkan hasil penilaian penugasan dan tes tertulis adalah 3,10 di Siklus yang kedua, dan ini mengalami kenaikan dari Siklus pertama yang awalnya baru mencapai nilai rata-rata sebesar 2,80.

Besarnya nilai rata-rata ini sangat dipengaruhi oleh hasil penilaian tes tertulis, karena pada penilaian tes tertulis masih ada beberapa peserta didik yang belum mencapai nilai ketuntasan untuk beberapa KD yang harus dicapai. Pada Siklus pertama, hanya 16 peserta didik yang sudah melampaui batas nilai KKM untuk hasil tes tertulis dengan nilai rata-rata sebesar 2,67, walaupun nilai penugasan yang diraih semua peserta didik sudah melampaui nilai KKM.Pada Siklus kedua, sudah ada peningkatan untuk hasil tes tertulis, dengan nilai rata-rata sebesar 3,08 dan nilai penugasan pun semakin mengalami peningkatan dengan capaian yang diraih peserta didik seluruhnya melampaui batas KKM. Adapun presentasi kenaikan untuk kompetensi pengetahuan yang dicapai peserta didik saat belajar Turunan Fungsi dari pra-Siklus ke Siklus 1 adalah 55 persen dan dari Siklus 1 ke Siklus 2 adalah sebesar 30 persen.

Adanya peningkatan sikap positif peserta didik, bukan hanya berdampak pada peningkatan nilai rata-rata pengetahuan, namun berpengaruh pula terhadap peningkatan capaian nilai rata-rata untuk kompetensi keterampilan. Nilai yang dicapai peserta didik dari nilai rata-rata optimum setiap KD yang awalnya hanya sebesar 2,96 di Siklus pertama, naik menjadi 3,16 di Siklus yang kedua. Besarnya presentasi kenaikan dari pra Siklus ke Siklus pertama sebesar 36 persen, dan dari Siklus pertama ke Siklus kedua sebesar 20 persen. Selain itu, pada kompetensi keterampilan ini ternyata nilai optimum yang diraih peserta didik mengalami peningkatan dari Siklus pertama ke Siklus yang kedua, Siklus pertama hanya dinilai tertinggi 3,33 untuk capaian optimum yang diraih peserta didik, dan di Siklus yang kedua sudah ada peserta didik yang mencapai nilai optimum 
3,67 dari hasil penilaian tes praktek maupun tugas proyeknya.

Model pembelajaran ini sudah dapat membuat hampir seluruh peserta didik mencapai nilai tuntas pada kompetensi pengetahuan, dan seluruhnya mencapai nilai tuntas pada kompetensi keterampilan maupun kompetensi sikap. Bukan hanya peserta didik yang memang sudah pandai matematika yang selalu meraih nilai tuntas, namun peserta didik yang awalnya selalu harus mengalami pembelajaran remedial apabila diberikan tes tertulis, setelah proses pembelajaran menggunakan model PjBLpeserta didik dapat meraih nilai tuntas secara klasikal untuk materi yang diujikan. Ini menunjukkan bahwa terdapat peningkatan hasil belajar peserta didik kelas XI.MIA-4 berdasarkan kompetensi sikap, pengetahuan dan keterampilan dengan menggunakan model PjBL.

Pernyataan ini diperkuat dengan hasil penelitian Thomas (2000), yang menunjukkan bahwa hasil belajar peserta didik menggunakan model PjBL naik hampir 26 persen dan ada peningkatan yang signifikan kemampuan memecahkan suatu masalah menggunakan model PjBL. Menurut Purworini (2006), bahwa model PjBL dapat meningkatkan hasil belajar peserta didik, meningkatkan aktivitas dan keterlibatan peserta didik dalam pembelajaran, menumbuhkan kreativitas dan karya peserta didik, lebih menyenangkan, bermanfaat serta lebih bermakna. Proses pembelajaran dengan menggunkan model $P j B L$, membuat peserta didik bukan hanya sekedar mempelajari rumus matematika, namun bagaimana menerapkan konsep yang mereka pelajari dalam kehidupan sehari-hari, untuk mata pelajaran lain maupun bermanfa'at saat menyelesaikan masalah matematikadengan topik yang berbeda.

\section{SIMPULAN DAN SARAN}

\section{Simpulan}

Berdasarkan hasil dan pembahasan penelitian seperti yang telah diungkapkan pada Bab sebelumnya, secara umum dapat disimpulkan bahwa Model PjBL dapat meningkatkan hasil belajar peserta didik, baik dari aspek sikap, pengetahuan, dan keterampilan pada pokok bahasan Turunan Fungsi berdasarkan Kurikulum 2013 Tahun Pelajaran 2014/2015di SMA Negeri 1 Sungailiat. Adanya peningkatan sikap positif peserta didik, bukan hanya berdampak pada peningkatan nilai rata-rata pengetahuan, namun berpengaruh pula terhadap peningkatan capaian nilai rata-rata untuk kompetensi keterampilan. Proses pembelajaran yang bukan hanya menjadikan peserta didik lebih aktif dan kreatif, namun melalui model $P j B L$ peserta didik diarahkan untuk terbiasa bekerjasama dalam kelompok (berkolaborasi), membangun solusi atas masalah nyata atau sebagai pemecah masalah, serta meningkatkanpemahaman secara mendalam karena peserta didik perlu mendapatkan dan menerapkaninformasi, konsep, dan prinsip-prinsip selama pembelajaran. Peserta didik pun memiliki 
potensi untuk meningkatkan kompetensi dalam berpikir (belajar danmetakognisi) karena peserta didik ditugaskan untuk memformulasi rencana, kemajuandan mengevaluasi solusi.

Proses pembelajarannya, dimulai dengan menyajikan pertanyaan mendasar sebagai bahan tugas proyek. Kemudian peserta didik membuat desain/rencana kegiatan untuk menyelesaikan tugas proyek, dan menyusun jadwal kegiatan yang akan dilakukan mulai dari persiapan, pelaksanaan sampai pelaporan. Proses selanjutnya adalah kegiatan monitoring kemajuan penyelesaian tugas proyek, dimana guru menjadi tempat berkonsultasi bagi peserta didik yang mengalami kendala selama penyelesaian tugas proyek. Setelah peserta didik menyusun laporan hasil penyelesaian tugas proyek dan dikumpulkan sesuai dengan batas waktu penyelesaian tugas proyek yang sebelumnya telah ditetapkan, pendidik menguji hasil pekerjaan peserta didik melalui sesi presentasi. Langkah terakhir, peserta didik diminta untuk menyampaikan pengalamannya selama menyelesaikan tugas proyeknya, apa saja kendala dan permasalahan yang dihadapi dan bagaimana mengatasinya, serta hal positif apa yang dirasakan setelah menyelesaikan tugas proyek ini. Melalui rangkaian proses pembelajaran dengan menggunakan model PjBL. Terjadinya peningkatan hasil belajar peserta didik berdasarkan capaian keseimbangan kompetensi sikap, pengetahuan dan keterampilan dengan lebih optimal sehingga kualitas pembelajaran dapat lebih tingkatkan dan berdampak pada peningkatan mutu pendidikan.

\section{Saran}

Mengacu pada simpulan, seorang guru wajib mengembangkan berbagai model pembelajaran sesuai dengan karakteristik peserta didik dan materi yang akan dibahas. Pada saat akan menerapan model PjBL, guru harus memperhatikan beberapa hal, diantaranya: tahapan-tahapan dalam melaksanakan model PjBL, pemilihan materi pembelajaran, pemilihan masalah untuk memunculkan pertanyaan yang mengarah pada proyek peserta didik dan memperhatikan penggunaan waktu yang diperlukan dalam pembelajaran. Sudah menjadi kenisca jikalau guru mampu menciptakan suasana pembelajaran yang mampu menggali pengetahuan peserta didik dan mampu membuat suasana belajar di kelas menjadi lebih menarik dan menyenangkan, sehingga mampu meningkatkan suasana pembelajaan yang kondusif dan menyenangkan serta pembelajaran yang berkualitas. Selain itu, pembelajaran dengan menggunakan Model PjBL yang setiap sintak/fasenya mengandung rangkaian kegiatan pembelajaran saintifik. Hal ini dapat dicoba untuk di gunakan pada materi lain pada mata pelajaran matematika peminatan, maupun pada mata pelajaran lainnya, baik di kelompok wajib, peminatan, maupun lintas minat dengan menyesuaikan karakteristik materi yang akan dibahas/diajarkan kepada peserta didik. 


\section{PUSTAKA ACUAN}

Bjorner, T., Kofoed, L.B., \& Pederson, J.R.B. 2012. Creative in Project Work-Student's Perception and barriers. International Journal of Engineering Education. Vol 28(3):545553.

Briggs, L. J. 1979. Instructional Design: Principles and Aplication. Engelwood Cliffs, New Jersey: Prentice-Hall, Inc.

Hakim, Thursan. 2005. Belajar Secara Efektif. Jakarta: Puspa Swara.

Heruman. 2010. Model Pembelajaran Matematika di Sekolah Dasar. Bandung: PT Remaja Rosdakarya Offset.

Johnson, E.B. 2010. Contextual Teaching and Learning: Menjadikan Kegiatan BelajarMengajar Mengasyikan dan Bermakna (Terjemahan: IbnuSetiawan).Bandung: Kaifa Learning.

Karso dan Damardjo. 1993. Dasar-Dasar Pendidikan MIPA UT. Depdikbud. Jakarta.

Kementerian Pendidikan dan Kebudayaan. 2014. Materi Pelatihan Implementasi Kurikikulum 2013 untuk Guru SMA/SMK.Jakarta: Diperbanyak oleh BPSDMK-PMP.

Kemmis, S. \& McTagger, R. 1990. The Action Research Planner. 3rd ed. Victoria: Deakin University.

Kunandar. 2013. Penilaian Autentik: Penilaian Hasil Belajar Peserta Didik Berdasarkan Kurikulum 2013 (Suatu Pendekatan Praktis). Jakarta: Raja Grafindo Persada.

Lawson, A. E. (1995). Science teaching and the development of thinking. Belmont, CA: Wadsworth Publishing Company.

Lindawati, Fatmariyanti, S.D., Maftukhin, A. 2013. Penerapan Model Pembelajaran Project Based Learning Untuk Meningkatkan Kreativitas Peserta didik MAN I Kebumen. Jurnal Radiasi.Vol. 3, No.1

Peraturan Menteri Pendidikan dan Kebudayaan No. 104 Tahun 2014 tentang Penilaian.Jakarta: diperbanyak oleh Departemen Pendidikan Nasional.

Purworini. 2006. Pembelajaran Berbasis Proyek Sebagai Upaya Mengembangkan Habit of Mind: Studi Kasus di SMP Nasional KPS Balik Papan. Jurnal Pendidikan Inovatif, 1 (4): $17-19$.

Rais, M. 2010. ModelProject Based-LearningSebagai UpayaMeningkatkan Prestasi Akademik Mahapeserta didik.Jurnal Pendidikan dan Pengajaran, Jilid 43, Nomor3, Oktober2010, hlm. 246-252.

Ruseffendi, E.T. 1991.PenilaianPendidikandan Hasil Belajar Siswa Khususnya dalam Pengajaran Matematika untuk Guru dan Calon Guru. Bandung. Diktat.

Soedjadi, R. 1999. Kiat Pendidikan Matematika di Indonesia (Konstatasi Keadaan Masa Kini Menuju Harapan Masa Depan). Jakarta: Ditjen Dikti Depdikbud.

Suparno, P. 2008. Action Research: Riset Tindakan untuk Pendidikan. Jakarta: Grasindo 
The George Lucas Educational Foundation. 2005. Instructional Module Project Based Learning. http://www.edutopia.org/modules/PBL/whatpbl.php

Diakses tanggal 5November 2007.

The George Lucas Educational Foundation.2012.Project-Based Learning Research Review. http://www.edutopia.org/pbl-research-learning-outcomes.

Diakses tanggal 28Desember 2015.

Thomas, J.W. 2000. A Review of Research On Project Based Learning. Electronic Journal of Science Education. San Rafael - California: The Autodesk Foundation.

Trianto. 2007. Model-model Pembelajaran Inovatif Berorientasi Konstruktivistik. Jakarta: Prestasi Pustaka.

Undang-Undang Republik Indonesia Nomor 20 Tahun 2003 tentang Sistem Pendidikan Nasional. 2006. Jakarta: diperbanyak oleh Departemen Pendidikan Nasional.

Utami, R.P., Probosari, R.M., Fatmawati, U. 2015. Pengaruh Model Pembelajaran Project Based Learning Berbantu Instagram Terhadap Kemampuan Berpikir Kreatif Peserta didik Kelas X SMA Negeri 8 Surakarta. Jurnal BIO-PEDAGOGI, ISSN: 2252-6897 Volume 4, Nomor 1 April 2015 Halaman 47-52

Wahyu. 2009. Sikap. http://yudiuksw.multiply.com/journal/item/3. Diakses tanggal 10 Maret 2015.

Wena, M. 2009. Strategi Pembelajaran Inovatif Kontemporer. Jakarta: Bumi Aksara.

Widaningsih, D. 2010. Telaah Kurikulum Matematika Sekolah.Tasik Malaya: Paket Model PSPM FKIP UNSIL. 